\section{DOI: 10.32999/ksu2524-0838/2019-27-10 \\ УДК 577.175.1:612.017}

Швець В. А., Гасюк О. М.

УЧАСТЬ ЦИТОКІНІВ У АДАПТАЦІЙНИХ РЕАКЦІЯХ (ОГЛЯД ЛІТЕРАТУРИ)

\author{
Херсонський державний університет, м. Херсон, Україна \\ shvetsvika88@gmail.com
}

Проведено ретроспективний аналіз розвитку відомостей щзодо системи циитокінів $з$ 20-х років XX cm. і до сьогодення. 3'ясовано, яким чином розвивалися відомості стосовно ідеї існування «несподіваних» медіаторів, які мають гормоноподібну дію, але гормонами не являються. Доведено, щуо иі речовини синтезуються не у спеціалізованих секреторних органах, а у різноманітних клітинах, які локалізовані по всьому організму і мають значну кількість клітин-мішеней. Приведено основні класифікації ичтокінів: за біохімічними та біологічними властивостями; за функиіональною приналежністю; за будовою; за участю y запальних реакиіях тощуо. Згідно сучасних відомостей, наведено загальну характеристику системи циитокінів та розкрито їх функціональні взаємовідносини.

Досліджено місие та роль медіаторів міжклітинних взаємодій в адаптаційних процесах в організмі при дії різних стресових факторів (емоційно-больового стресу, холодового впливу, фізичного навантаження тощь). Саме за зміною концентрації певного циттокіну можна відстежити та скорегувати негативний вплив вищеозначених факторів на організм.

Представлено дані літератури стосовно участі імунорегулюючих ичттокінів (Інтерлейкін-1, -2, -4, та -6) в реалізації стрес-реакиії. Також розглянуто явище «цитокінового шторму», як неспецифічної (потенційно летальної) генералізованої реакції на дію надмірних подразників.

У статті увага спрямована на непрямі ефекти цчитокінів (плейотропна біологічна дія), коли один і той же циитокін може діяти на багато типів клітин, викликаючи різні ефекти в залежності від виду клітин-мішеней.

На даний час актуальним є вивчення участі изитокінів в реалізації адаптаційних процесів та підтриманні алостазу, тож подібні дослідження $\epsilon$ своєчасними $i$ потребують подальшої розробки.

Ключові слова: циитокіни, «циитокіновий иторм», адаптація, стрес.

Shvets V. A., Hasiuk O. M.

\title{
CYTOCINS PARTICIPATION IN ADAPTATION REACTIONS
} (LITERATURE REVIEW)

$A$ retrospective analysis of the development of the information about the system of cytokines from the 20-ies of XX century and to the present has been carried out. It was discovered how the idea has developed about the existence of «unexpected» mediators that have a hormonal effect, but are not hormones. It is proved that these substances are synthesized not in specialized secretory organs, but in various cells that are localized throughout the body and have many target cells. The basic classification of cytokines is given: according to the 
biochemical and the biological properties; by the functional attribute; by the structure; with the participation in inflammatory reactions, etc.

According to the modern information, a general description of the system of cytokines is presented and their functional relations are revealed.

The place and the role of mediators of intercellular interactions in adaptive processes in an organism under the influence of various stress factors (the emotional pain stress, the cold stress, the physical activity, etc.) are investigated. It is by changing the concentration of a particular cytokine that it is possible to trace and to correct the negative influence of the abovementioned factors on the body.

The literature data on the participation of immunoregulating cytokines (Interleukin -1, -2, 4, and -6) in the implementation of the stress reaction are presented. Also, the phenomenon of the "cytokine storm» as a non-specific (potentially lethal) generalized reaction to the effect of excessive stimuli is considered.

The investigation attracts attention to the indirect effects of cytokines (the pleiotropic biological action) when the same cytokine can act on many types of cells, causing different effects depending on the type of target cells.

Currently, it is actual to study the participation of cytokines in the implementation of adaptation processes and the maintenance of an alostasis, and such studies are timely and require the further development.

Key words: cytokines, "cytokine storm», adaptation, stress.

Мета - дослідити відомості 3 наукової літератури стосовно ролі цитокінів у реалізації адаптаційних реакцій в умовах впливу різних екстремальних факторів.

Найбільш чисельною групою біологічно активних речовин, які беруть участь у багатьох фізіологічних і патологічних процесах, є цитокіни [5]. Це клас ендогенних поліпептидних медіаторів міжклітинних взаємодій, які регулюють та підтримують клітинний i тканинний гомеостаз, сприяють формуванню захисних реакцій організму при впливі чужорідних факторів i порушенні цілісності тканин $[5,33]$.

Цитокіни є своєрідними сигнальними молекулами, які після зв’язування 3 конкретними рецепторами на різних типах клітин, індукують активацію, проліферацію або міграцію клітин-мішеней [43]. В сукупності вони утворюють своєрідну мережу, функціонування якої носить універсальний, вроджений і стереотипний характер. Згідно сучасних уявлень, така мережа $є$ однією з найважливіших регуляторних систем організму нарівні з нервовою, кровоносною та ендокринною [5, 6, 19, 32].

Ретроспективний аналіз уявлень про цитокіни можна почати 3 20-х років ХХ ст. Цей час характеризується великою кількістю досліджень, які привели до відкриття нових біологічно активних речовин. Деякі 3 них, після подальшого вивчення, було віднесено до цитокінів [25, 30].

В той час виникла нова ідея щодо існування «несподіваних» медіаторів, які мають гормоноподібну дію, але гормонами не являються. Такі речовини синтезуються не у спеціалізованих секреторних органах, а у різноманітних 
клітинах, які локалізовані по всьому організму і мають велику кількість «клітин-мішеней» [41].

Так у 1926 році було опубліковано роботу Х. Цинссера і Т. Тамія [58], де в дослідах по вивченню бактеріальної алергії показано, що певні продукти життєдіяльності активованих лейкоцитів помітно впливають на клітинні стінки кровоносних судин (активують ендотелій).

У 1932 р. А. Річ і М. Льюїс [54] визначили, що в культурі тканини, сенсибілізованої до туберкульозної бактерії, в присутності певного антигену швидко гинуть макрофаги та значно сповільнена міграція фагоцитів.

У 1957 р. в роботі А. Айзекса і Дж. Лінденманна [50] вперше згадується про відкриття інтерферону. Автори описали чинники, які продукувалися інфікованими вірусом клітинами (in vitro) та захищали неінфіковані клітини після їх додавання в заражену культуру [34]. Продовжуючи подібні дослідження, вже у 1958 р. Б. Ваксманом і М. Матолтсі [56] підтверджено, що туберкулін стимулює активність макрофагів.

1960-ті - початок 1980-х років вважається етапом виокремлення різних речовин із супернатантів клітинних культур та гуморальних медіаторів імунної відповіді, які вдавалося виділити в чистому вигляді. Ці рекомбінантні препарати при їх застосуванні втрачали свою біологічну активність через те, що вони не здатні самостійно функціонувати. Це пов'язано з функціонуванням цих медіаторів в системі, що отримало назву «цитокінова сітка» [30].

У 1961 р. Дж. Фесслер у своїй роботі [47] показав, що в культурі in vitro ендогенні пірогени продукують мононуклеарні клітини людини, миші та кролика. Пізніше, групою дослідників (Д. Плузнік, Л. Сакс, 1965; Т. Бредлі і Д. Меткальф, 1966) описано колонієстимулюючі фактори, які спричиняли розростання гранулоцитарних і макрофагальних клітин в культурах на напіврідкому агарі. Автори дали назву цьому фактору росту - Інтерлейкін-3 $[30,34]$.

У 1966 р. група вчених (Дж. Девід, Б. Блум та Б. Беннет) [36] у своїх дослідженнях виокремили перший ідентифікований фактор інгібування міграції макрофагів - цитокін MIF. Автори з'ясували, що лімфоцити, сенсибілізовані до мікобактерії, в присутності антигену продукують цей гуморальний фактор. Зараз MIF визнаний мультипотентним цитокіном, який бере участь у регуляції імунних та запальних реакцій.

Після цього відкриття, для виявлених гуморальних чинників почали застосовувати терміни «лімфокіни» і «монокіни» в залежності від того, що було відомо про клітини-продуценти (відповідно лімфоцити або моноцити) та сформована так звана концепція «інтерлейкінів - медіаторів міжлейкоцитарної взаємодії» [34]. 
Проривом можна вважати дослідження Стенлі Коена, який у 1974 р. в супернатанті культивованих клітин нирки зеленої мавпи, інфікованих вірусом $S V$ 40, виявив фактор, ідентичний лімфоцитарному MIF. Дослідник припустив, що гуморальні фактори, які секретуються клітиною, не $\epsilon$ винятковою особливістю лімфоцитів і моноцитів та запропонував більш універсальний термін «цитокін», який є загальноприйнятим і в теперішній час [42].

Пізніше було виявлено, що в сировотці крові мишей, сенсаболізованих M. bovis, накопичується клітинний фактор, який спричиняв розсмоктування пухлин [39]. Цей медіатор назвали фактором некрозу пухлин (кахектін, TNF) $[34,40]$.

У 1976 р. Морган із співавторами з'ясували, що супернатант зі змішаної культури лейкоцитів має бластогенний вплив на лімфоцити. Це був фактор росту Т-клітин, який з часом отримав назву Інтерлейкін-2 [34].

У 1977 р. ендогенний піроген, досліджуваний Дж. Фесслером [47], було очищено до стану гомогенності [44]. Було встановлено його ідентичність 3 продуктом макрофагів, який був описаний як ендогенний медіатор лейкоцитів, що має здатність індукувати запальні реакції гострої фази. На даний час відомо, що цей фактор - Інтерлейкін-1 $\beta$.

У 1978 р. для цілого ряду речовин, які стимулюють ріст та функціональну активність Т- i В-лімфоцитів, було введено термін «інтерлейкіни», тобто медіатори, що здійснюють зв'язок між лейкоцитами [5].

У 1980 р. прийнята номенклатура інтерферонів, в якій виділяють $\alpha$ (макрофагальний), $\beta$ (фібробластний) та $\gamma$ (лімфоцитарний, імунний) інтерферони [34]. Також з середини 1980-х і до теперішнього часу широко використовуються методи молекулярного клонування: отримання трансгенних мишей, нокаутних ліній. Прикладом $\epsilon$ використання трансгенних мишей по TNF на основі геному лінії C57Bl/6 для вивчення експресії гена фактора некрозу пухлин [27]. Такі дослідження поступово вносять розуміння про співвідношення структури і функції цитокінів та розширюють обсяг інформації про ці речовини.

Та лише в 1990-х роках була відкрита субодинична будова рецепторів цитокінів і сформовано поняття «цитокінова мережа» («цитокінова сітка»), в якій кожен цитокін функціонально пов'язаний з іншими. Вплив на одну 3 ланок цієї системи неминуче відображається на функціях інших її складових $[5,6,19]$.

На початку 2000-х років, завдяки використанню генетичного аналізу, стали відомі нові цитокіни, а також запроваджена концепція «генних мереж» цих медіаторів. Вона активно використовується для дослідження роботи 
цитокінових взаємодій. На сьогодні відомо приблизно 200 окремих речових, що належать до групи цитокінів [25, 30, 43].

Отже, одним із важливих сучасних напрямків дослідження є прояви та сукупний вплив цитокінів на процеси, які відбуваються в організмі та спричиняють швидку генерацію вродженої і адаптивної імунної відповіді. Цей каскад медіаторів запалення викликає руйнування тканин у вогнищі запалення, одночасно поширюючи реакцію на сусідні тканини, та набуває системного характеру, охоплюючи весь організм в цілому [40].

У літературі все частіше застосовується термін «цитокіновий шторм» («гіперцитокінемія», «цитокінова буря»). Він позначає потенційно летальну реакцію імунної системи через масивне вивільнення і порушення регуляції цитокінів, призводить до шоку, поліорганної недостатності та навіть смерті [40]. Ця реакція є системним проявом високої активності імунокомпетентних клітин, під час якої відбувається виділення близько 150 медіаторів запалення, не лише цитокінів, а й радикалів вільного кисню і факторів коагуляції [20]. Вперше термін «цитокіновий шторм» був використаний для опису хаотичного патофізіологічного стану, що виникає під час гострого відторгнення трансплантата [46]. А вже в 2003 р. була виявлена «цитокінова буря», пов'язана з реакцією на грип, а згодом - на різні вірусні, бактеріальні або грибкові інфекції. Однак, немає чіткого визначення того, що таке «цитокіновий шторм». Важливим $\epsilon$ те, що синдром сепсису, індукований каскадом цитокінів, і досі є однією із головних проблем охорони здоров'я $[20,48]$. На жаль, незважаючи на величезний прогрес у дослідженнях сепсису, всі клінічні випробування з метою зменшення запальної реакції або націлювання на вивчення цитокінів при цьому, не вдалися $[6,40,57]$.

В даний час розпізнано від Інтерлейкіну-1 до Інтерлейкіну-37, які можуть бути звільнені у важкій «цитокіновій бурі» [40, 43]. Та в літературі описано недостатньо даних стосовно ролі кожного з цих гуморальних факторів в цитокіновому каскаді. За даними щодо прозапальної ланки до фактору некрозу пухлин, певні цитокіни (Інтерлейкін-1, -12, -17), ймовірно, сприятимуть результату «повномасштабного шторму» в організмі $[40,48]$.

Таксономія цитокінів $є$ дуже складною і заснована, як на синхронізації відкриття, так і на розділенні за функцією, структурою або ефекторною системою. Сам термін «цитокін» позначає приблизно 100 окремих генів, які кодують цитокіни або цитокін-подібні білки [43].

Згідно останніх даних [40] цитокіни можна розділити на кілька категорій: інтерлейкіни (ІЛ), інтерферони, хемокіни, фактори некрозу пухлин (ФНП) і фактори росту.

За різними авторами можна виділити декілька основних класифікацій цитокінів: 
2004);

- за біохімічними та біологічними властивостями (Симбирцев А.С.,

- за функціональною приналежністю (Хаитов Р.М. и др., 2000;. А.К. Abbas at al., 2007; C.A. Janeway Jr. at al., 2008 та ін.);

- за типами рецепторів, за допомогою яких цитокіни здійснюють свої функції (Ihle J. at al., 1995; Holmes W. at al., 1991; Fucata T. at al., 1996);

- за будовою, враховуючи амінокислотну послідовність, та насамперед третинну структуру білка, яка відображає еволюційне походження молекул (Nicola N., 1994) [5, 29].

Та найбільш обширною $\mathrm{i}$ загальноприйнятою $\epsilon$ структурнофункціональна класифікація, в якій всі цитокіни поділені на групи, 3 урахуванням їх біохімічної та біологічної активності, а також особливостей будови їх молекул і рецепторів [21].

За цією класифікацією цитокіни поділяють на такі родини: інтерферони I типу; фактори росту гемопоетичних клітин; родина IЛ-1 і фактора росту фібробластів; родина ФНП; родина ІЛ-6; хемокіни; родина ІЛ-10; родина ІЛ12; цитокіни Т-хелперних клонів; родина ІЛ-17; суперродина фактора росту нервів, тромбоцитарного ростового фактора i трансформуючих ростових факторів; родина епідермального ростового фактора та родина інсуліноподібних ростових факторів.

Функціонально, цитокіни в залежності від типу Т-лімфоцитів, які їх синтезують під час імунної відповіді, поділяють на Th1-типу (ІЛ-2, IЛ-12, інтерферон- $\gamma$, ФНП- $\alpha$ ) та Тh2-типу (ІЛ-4, ІЛ-5, ІЛ-10, ІЛ-13) в залежності від кінцевого балансу їх ефектів [45].

За функціональною роллю в запальних реакціях цитокіни поділяють на ранні (ІЛ-1, ІЛ-6, ФНП- $\alpha$ ) і пізні (ІЛ-3, ІЛ-4, ІЛ-5, інтерферон- $\gamma$ ); вроджені (ФНП, ІЛ-4, ІЛ-6, ІЛ-12, ІЛ-18) і адаптивні (інтерферон- $\gamma$, ІЛ-13, ІЛ-5, ІЛ-10); прозапальні (ІЛ-1 $\beta$, ІЛ-2, ІЛ-6, ІЛ-8, ІЛ-12, ІЛ-17, інтерферон- $\gamma$ ) і протизапальні (ІЛ-4, ІЛ-5, ІЛ-10, ІЛ-13) [21].

Та, незважаючи на таку широку номенклатуру та класифікацію, спектри біологічних активностей інтерлейкінів у значній мірі перекриваються: один і той же процес може стимулюватися в клітині більш ніж одним цитокіном [12].

Досить важливим та важким при вивченні цих речовин $є$ те, що цитокіни мають плейотропну біологічну дію, тобто один і той же медіатор може діяти на багато типів клітин, викликаючи різні ефекти в залежності від виду клітин-мішеней. Також для цих гуморальних речовин міжклітинної взаємодії характерна взаємозамінність біологічної дії, тобто кілька різних цитокінів можуть викликати один і той же ефект або володіти схожою активністю (індукують або пригнічують синтез самих себе, інших цитокінів та їх рецепторів) [4]. 
За даними Вастьянова Р.С. [2] процеси синтезу і вивільнення цитокінів регулює нервова система. Нейропептиди i нейротрансмітери, що секретуються нейронами, безпосередньо впливають на активність цитокінів, забезпечуючи вираженість імунних реакцій. У роботах $[2,51]$ показана здатність синтезувати цитокіни, а також їх функціонально активні рецептори в основному «на замовлення». Така здатність значно зростає при дії факторів, що призводять до розвитку дистресу і хвороб центральної нервової системи.

Однією 3 найважливіших функцій системи цитокінів $є$ забезпечення узгодженої дії імунної, ендокринної та нервової систем під час розвитку реакції запалення. В свою чергу, регуляція процесів запалення та імунної відповіді цитокінами $\epsilon$ необхідною умовою для розвитку адекватних захисних та адаптаційних реакцій організму, але порушення їх контролю може стати причиною виникнення захворювань. Отже, недостатня або надмірна продукція цитокінів призводить до розвитку патологічних станів в організмі [31].

Цікавим $\epsilon$ те, що стан імунних функцій організму багато в чому визначається співвідношенням прозапальних і протизапальних цитокінів, роль яких, за вітчизняною та зарубіжною літературою, досить неоднозначна, а дані дуже суперечливі [21].

Також є відомості про те, що цитокіни можуть відігравати певну роль у регуляції сну, апетиту, адаптації до фізичних навантажень, та експресія більшості з них у здорових тканинах дуже низька. Однак, синтез цитокінів різко збільшується у результаті «тканинного стресу», який спричиняється різними клітинними факторами, такими як періоди швидкого клітинного росту, ремоделювання тканини, хвороби, в тому числі травми, або інфекції. Специфічні цитокіни $є$ відповіддю організму на загрозу порушення тканинного гомеостазу. Їх активність залежить від характеру (наприклад, вірусна, бактеріальна, запальна), типу клітин чи тканини, гормонального балансу та від профілю інших цитокінів, які синтезуються на цій ділянці. За здатністю деяких цитокінів регулювати гомеостатичні процеси в тканинах, віддалених від місця їх синтезу, встановлено роль цих речовин як ключових регуляторів системних і місцевих відповідей організму на пошкодження $[10$, 33].

В даний час для пояснення розвитку пристосувальних змін застосовується теорія алостазу, за якою адаптивні процеси спричиняють перехід гомеостазу на інший рівень функціонування під впливом змін концентрації «медіаторів алостазу» - стресорних гормонів, а також прозапальних та протизапальних інтерлейкінів. Так в роботі [3] показано, що визначення інтерлейкінового профілю дітей зі слуховою сенсорною депривацією, має практичне значення при розкритті адаптивних змін, які 
реалізуються шляхом залучення нейро-ендокринних медіаторів і системи цитокінів.

Актуальним питанням сучасної фізіології є роль та участь цитокінів в адаптаційних процесах організму за дії на нього фізичного навантаження, емоційно-больового стресу, високої або низької температури, радіаційного опромінення та ін. Саме за зміною концентрації певного цитокіну можна відстежити та скорегувати негативний вплив вищеозначених факторів на організм.

Ще Ганс Сельє $(1960,1972,1979)$ писав, що будь-які зміни зовнішнього або внутрішнього середовища $є$ стресорним фактором, який вимагає змін рівня активності різних систем організму та має ряд спільних сидромів [18]. В даний час термін «стрес» розглядається в літературі в двох основних аспектах - як неспецифічна (загальна) реакція організму на різні впливи (фізичні або психологічні), що порушують його гомеостаз, а також як відповідний стан нервової системи. Основною характеристикою цього стану $€$ «неспецифічне навантаження» гіпоталамо-гіпофізарно-адренокортикальної системи, що викликає зміни в різних органах.

При активації стрес-реакції важливе місце займає активація системи, відповідальної за адаптацію до даного стресора та здійснення подальшої адаптації (відновлення гомеостазу). В свою чергу стрес - це одночасна активація стрес-системи та стрес-лімітуючої системи. До стрес-системи входить центральна складова та периферична. Саме цитокіни разом із тахікінами (нейропептидами), симпато-адреналовою та гіпоталамогіпофізарно-адреналовою системами входять до складу периферичної складової стрес-системи [9, 17].

Дані літератури про участь імунорегулюючих цитокінів (IЛ-1, IЛ-4, та ІЛ-6) в реалізації стрес-реакції до теперішнього часу мають суперечливий характер. Є відомості як про стимуляцію, так і про пригнічення їх продукції і рівня в крові при стресі $[38,49]$.

Однією з причин відмінностей в зміні продукції цитокінів при стресі $є$ різна інтенсивність і тривалість екстримальних стресових впливів, а також стрес-індукованих змін рівня гормонів. Будучи регуляторними молекулами, цитокіни відіграють важливу роль у здійсненні реакцій вродженого і адаптивного імунітету, забезпечують їх взаємозв’язок, контролюють гемопоез, запалення, загоєння ран, утворення нових кровоносних судин i багато інших життєво важливих процесів [11].

У роботах (Cannon J.G., 1986.; Gadek-Michalska A. et al., 2008) показано, що прозапальний цитокін - ІЛ-1ß запускає каскад секреції інших цитокінів в організмі і $є$ одним із медіаторів гострої фази стресорної реакції, що активуючи впливає на гіпоталамо-гіпофізарно-наднирковий комплекс. Також секреція ІЛ-1ß може бути викликана гормонами стресу, пов'язаними 3 
фізичним навантаженням [38, 49]. Так, згідно з даними (Пальцев М.А., 1996; Кетлинский С.С., 2008;) ІЛ-4 навпаки - знижує функціональну активність гіпоталамо-гіпофізарно-надниркової осі та пригнічує продукцію прозапальних цитокінів, а саме, ІЛ-1, ІЛ-6, ФНП- $\alpha$, і стимулює утворення рецепторного антагоніста ІЛ-1ра $[5,14]$.

У роботі (Бабийчук В.Г., 2007) показано, що після 9 сеансів кріовпливу спостерігається істотне збільшення вмісту в сироватці крові гранулоцитарного колонієстимулюючого фактору, що може свідчити про стимулюючий вплив дії низьких температур на адаптивні можливості імунної системи i, зокрема, її гуморальної ланки. Також було показано, що кількість ІЛ-4 була нижче, ніж в контролі. Після дії холоду потреба в активації ІЛ-4 була відсутня, що дає підстави припускати про відновлення фізіологічних співвідношень між рівнем продукції прозапальних та протизапальних цитокінів [1]. Згідно з дослідженнями $[1,8,35]$ встановлено, що ритмічні холодові впливи істотно знижують вміст прозапальних цитокінів в сироватці крові літніх людей. Можна вважати, що ритмічні холодові впливи адекватно коригують порушену функцію цитокінової ланки імунної системи.

За даними [13] рівні протизапальних цитокінів (ІЛ-4 та ІЛ-10) в тканині кісткового мозку були підвищеними після дії 6-годинного емоційнобольового стресу і зберігалися такими через дві години після. Істотне підвищення рівня протизапальних цитокінів спостерігалося через декілька днів після закінчення 6-годинного емоційно-больового стресу. Це в певній мірі компенсує шкідливу дію стресу на організм i супроводжує проліферативні процеси, які почалися в кістковому мозку через 1-2 доби після стресу. Через п'ять діб після дії 6-годинного емоційно-больового стресу, рівні ІЛ-4 та ІЛ-10 в кістковому мозку були достовірно вище в порівнянні з контролем, що є логічним підсумком відновних процесів [13].

За дослідженнями [23] видно, що цитокіни здатні модулювати функції серцево-судинної системи, хоча здорове серце не синтезує цитокіни, проте кардіоміоцити в умовах ішемії можуть їх продукувати. У роботах $[7,26]$ показано, що при розвитку ішемічного інсульту існує пряма залежність між зміною вмісту прозапальних цитокінів (ІЛ-1, ФНП- $\alpha$ і ІЛ-6), активністю процесів вільнорадикального окислення і кінцевими розмірами інфаркту мозку. Проте, спостерігається одночасне значне збільшення вмісту цих прозапальних цитокінів в периферичній крові при розвиткові експериментального ішемічного інсульту. Так як ІЛ-1 і ФНП- $\alpha$ потужними індукторами ІЛ-6-синтетази в астроцитах: швидке збільшення вмісту мікрогліальних ІЛ-1 $\beta$ в перші 1-2 години церебральної ішемії викликає посилений синтез ІЛ-6. Тканинна гіпоксія i пошкодження міокарда призводять до надлишку синтезу цитокінів, що порушує ендотелій-залежну 
релаксацію периферичних судин. Так під впливом гострого стресу (60хвилинне обмеження рухової активності) утворюються прозапальні ІЛ-1 $\beta$ і ФНП- $\alpha$ [23].

В роботах (Кетлинский С.А., Симбирцев А.С., 2008; Симбирцев, А.С., 2004; Ярилин А.А., 1999; Павлова, В.И., Мамылина Н.В., 2012) підкреслено, що велику роль при адаптації до фізичних навантажень відіграє активація імунної системи зі зміною вмісту цитокінів, які забезпечують розвиток захисних реакцій організму і здійснюють підтримання гомеостазу. За даними наукової літератури, зрушення в цитокіновому каскаді під впливом фізичних навантажень аналогічні з такими при запальних і септичних станах $[5,13,22$, 34].

Показано, що при стресовій реакції норадреналін дозозалежно стимулює синтез ІЛ-6 в астроцити, який в свою чергу активізує каскадний синтез прозапальних цитокінів ІЛ-1, ІЛ-2 і ФНП- $\alpha$. Активація Т-клітинного цитокінового каскаду викликає підвищення продукції органоспецифічних аутоантитіл, що призводить до розвитку аутоімунних реакцій і станів, пов'язаних 3 пошкодженням органів i систем, прикладом яких $\epsilon$ кардіоміопатія. У дослідженні [53] вказано на кореляційну залежність між рівнем ІЛ-1 і креатинкінази, при цьому встановлено, що підвищення вмісту ІЛ-6 пов'язано з пошкодженням м'язової тканини.

Також встановлено, що динаміка виділення цитокінів характеризує імунну відповідь на зростаюче фізичне навантаження і зумовлює розвиток запальних процесів в м'язовій тканині [28]. У дослідженнях [15, 37, 52, 55] показано, що інтенсивні фізичні вправи викликають запальну реакцію, активність якої залежить від активності впливу фізичного навантаження, в якій $є$ значно підвищеною концентрація прозапальних цитокінів, таких як ІЛ6, ІЛ-12, ІЛ-18, ФНП- $\alpha$ та ІЛ-1ра. Так було виявлено 100-кратне збільшення продукції ІЛ-1ра та ІЛ-6 у марафонців після бігу [55].

Після будь-якого пошкодження, в тому числі фізичного перенапруження, в організмі розвивається комплекс захисних фізіологічних реакцій, що об'єднуються поняттям «гостра фаза запалення». Запалення, як системний процес, пов'язане з комплексом «адаптивних білків» гострої фази запалення, синтез яких активується такими прозапальними цитокінами як ІЛ1, ІЛ-6, ІЛ-11, ФНП- $\alpha$, інтерфероном- $\gamma$ і катехоламінами [23].

За даними [13] встановлено, що в річному тренувальному циклі збільшується вміст прозапальних і протизапальних цитокінів: в підготовчому періоді рівень прозапальних цитокінів ІЛ-1, ІЛ-6 був вище відповідно на 71\% і 42\%; рівень протизапальних цитокінів ІЛ-10, ІЛ-4 на $118 \%$ і $60 \%$ в порівнянні 3 контролем; в змагальному періоді рівень ІЛ-1, ІЛ-6 перевищували контрольні значення на $94 \%$ і 60\% i, в середньому, на $13 \%$. 
Показники підготовчого періоду: рівень вмісту ІЛ-10, ІЛ-4 збільшився на $30 \%$ в порівнянні $з$ підготовчим періодом.

Отже, дія різних цитокінів достатньо не вивчена, адже цитокіни мають дуже широкий та різнорідний спектр впливу на організм. Важливо поглибити знання про роль цитокінового каскаду в реалізації адаптаційних змін в організмі, що допоможе у визначенні особливостей функціонування нейроімунно-гуморальної системи регуляції і уточнити їх роль та значення, так як $\epsilon$ ймовірність їх негативного впливу. За матеріалами наукової літератури видно, що необхідно отримати нові дані про баланс симпато-адреналової системи в умовах цитокінової стимуляції імунної системи та визначити вплив цитокінового навантаження на реакції серцево-судинної системи та системи крові.

Аналіз цих даних матиме значення для розуміння фізіологічних механізмів адаптації організму ссавців, для виявлення характеру напруження функціональних систем, особливості якого детермінують утворення внутрішньосистемних та міжсистемних зв'язків. Тому перспективу подальшого вивчення вбачаємо в проведенні експериментального дослідження для визначення впливу цитокінової стимуляції на реакції систем організму (ендокринної, серцево-судинної, системи крові та ін.).

\section{ЛІТЕРАТУРА}

1. Бабийчук ВГ. Содержание цитокинов в сыворотке крови после ритмических холодовых воздействий. Проблемы криобиологии. 2007;17(4):356-364.

2. Вастьянов РС, Олейник ФФ Нейротропные эффекты цитокинов и факторов роста. Успехи физиол. наук. 2007;38(1):39-54.

3. Гасюк ОМ, Бесчасний СП. Інтерлейкіновий профіль дітей в умовах слухової сенсорної деривації. Український журнал медицини, біології та спорту. 2016;1(1):126-129.

4. Калиниченко ЛС. Цитокины в регуляции окислительных и антиоксидантных процессов в структурах головного мозга у крыс при остром эмоциональном стрессе [автореферат]. Москва: Научно-исследовательский институт нормальной физиологии имени П.К. Анохина; 2012. 26 с.

5. Кетлинский СС, Симбирцев АС. Цитокины. Москва: Фолиант; 2008. 552 с.

6. Козлов ВК. Цитокинотерапия: патогенетическая направленность при инфекционных заболеваниях и клиническая эффективность: Руководство для врачей. СанктПетербург: Альтер Эго; 2010. 148 с.

7. Левичкин ВД, Трофименко АИ, Каде АХ, Павлюченко ИИ, Мясникова ВВ, Пирогова НП, Занин СА. Характеристика цитокинового профиля и оксидативного статуса у крыс с экспериментальным ишемическим инсультом. Современные проблемы науки и образования. 2014;6:321.

8. Ломако ВВ, Шило АВ, Ломако СВ, Бабийчук ГА. Этологический анализ сочетанного применения холодовой и клеточной терапии у крыс с резерпиновой моделью депрессии. Пробл. криобиологии. 2005;15(3):471-472.

9. Меерсон Ф3, Пшенникова МГ. Адаптация к стрессорным ситуациям и физическим загрузкам. Москва: Медицина; 1988. 256 с. 
10. Ованесян ИГ. Современные представления о роли цитокинов в гомеостазе. Научномедицинский журнал. 2006;4:8-17.

11. Орадова АШ, Устенова ГО, Стабаева ГС. Методы исследования цитокинов (обзорная статья). Medicine. 2014;10:84-87.

12. Павлова АА, Павлова ИЕ, Бессмельцев СС. Цитокины и их роль в патогенезе множественной миеломы (Обзор литературы). Гематология. 2013;14:313-335.

13. Павлова ВИ, Мамылина НВ. Уровень провоспалительных и противовоспалительных цитокинов в крови у животных, подвергшихся действию эмоционально-болевого стресса. Цитокины и воспаление. 2012;11(1):46-48.

14. Пальцев МА. Цитокины и их роль в межклеточных взаимодействиях. Архив патологии. 1996;6:3-7.

15. Раджабкадиев РМ, Ригер НА, Никитюк ДБ, Галстян АГ, Петров АН, Евсюкова АО и др. Сопоставление уровня иммунорегуляторных цитокинов и некоторых антропометрических показателей высококвалифыцированных спортсменов. Медицинская иммунология. 2018;20(1):53-60.

16. Сарайкин ДА. Функциональное состояние организма юных спортсменов на разных этапах тренировочного процесса [автореферат]. Челябинск: Челябинский государственный педагогический університет; 2012. 24 с.

17. Саркисов С., редактор. Структурные основы адаптации и компенсации нарушенных функцій. Москва: Медицина; 1987. 446 с.

18. Селье Г. Очерки об адаптационном синдроме / Г. Селье. Москва: Медгиз; 1960. 254 c.

19. Серебренникова СН, Семинский ИЖ. Влияние цитокинов на клетки очага воспаления. Проблемы и перспективы современной науки. 2009;2(1):5-9.

20. Сидорчук АС, Богачик НА, Венгловська ЯВ. Роль системи цитокінів у патогенезі грипу. Клінічна та експериментальна патологія. 2008;7(2):130-133.

21. Симбирцев АС. Цитокины - новая система регуляции защитных реакций организма. Цитокины и воспаление. 2002;1:9-16.

22. Симбирцев АС. Цитокины: классификация и биологические функции. Цитокины и воспаление. 2004;3(2):16-22.

23. Солодков АП, Яцковская НМ, Крайнова НА, Нечаев ИН, Князев ЕН, Максименко ДГ. Провоспалительные цитокины и эндотелийзависимая дилатация при остром стрессе. Фундаментальные и прикладные проблемы стресса. Материалы III Междунар. науч.-практ, конф. Витебск. Витебск: ВГУ имени П.М. Машерова; 2013, c. $83-87$.

24. Стаценко ЕА. Профилактика и коррекция нарушений функционального состояния у высококвалифицированных спортсменов в условиях тренировочного процесса [автореферат]. Москва: Федеральный научный центр физической культуры и спорта; 2014. $47 \mathrm{c}$.

25. Сташкевич ДС, Филиппова ЮЮ, Бурмистрова АЛ. Актуальные вопросы иммунологии: система цитокинов, биологическое значение, генетический полиморфизм, методы определения : учеб. Пособие. Челябинск: Цицеро; 2016. 82 с.

26. Трофименко АИ, Каде АХ, Левичкин ВД, Нехай ФА, Занин СА. Динамика цитокинового статуса у крыс при моделировании ишемического инсульта. Современные проблемы науки и образования. 2014;2:326.

27. Фурсенко ДВ, Хоцкин НВ, Куликов ВА, Куликов АВ. Поведенческое фенотипирование мышей с нокаутом по фактору некроза опухоли. Вавиловский журнал генетики и селекции. 2015;19(4):394-398. 
28. Футорний CM, Імас СB, Осадча OI, Шматова ЕА, Глуховський ПВ. Особливості імунологічної адаптації під впливом значних фізичних навантажень. Науковий часопис НПУ імені М. П. Драгоманова. 2018;10(104):93-98.

29. Хаитов РМ, Игнатьева ГА, Сидорович ИГ. Иммунология : Учебник. Москва: Медицина; 2000. 432 с.

30. Хаитов РМ. Иммунология: учебник для вузов : 2-е изд., перераб. и доп. Москва: ГЭОТАР-Медиа; 2013. $521 \mathrm{c.}$

31. Черешнев ВА, Гусев ЕЮ. Иммунология воспаления, роль цитокинов. 2001;3(3):361368.

32. Шипилов МВ. Молекулярные механизмы “цитокинового шторма" при острых инфекционных заболеваниях. Лечебное дело. 2013;1:81-85.

33. Щокіна КГ, Штриголь СЮ, Дроговоз СМ. Досягнення та перспективи цитокінової та антицитокінової терапії. Науковий журнал МО3 України. 2013;1(2):121-129.

34. Ярилин АА. Основы иммунологии : Учебник. Москва: Медицина; 1999. 608 с.

35. Anisman H, Merali Z. Cytokines, stress and depressive illness. Brain. Behav. Immun. 2002;16(5):513-524.

36. Bloom BR, Bennett B. Mechanism of a reaction in vitro associated withdelayed-type hypersensitivity. Science. 1966; 153:80.

37. Cabral-Santos C, Gerosa-Neto J, Inoue DS, Panissa VL, Gobbo LA, Zagatto AM, et al. Similar anti-inflammatory acute responses from moderate-intensity continuous and highintensity intermittent exercise. J. Sports Science and Medicine. 2015; 14:849-856.

38. Cannon JG, Evans WJ, Hughes VA Meredith CN, Dinarello CA. Physiological mechanisms contributing to increased interleukin-1 secretion. Journal of Applied Physiology. 1986;61(5):1869-1874.

39. Carswell EA, Old LJ, Kassel RL, Green S, Fiore N, Williamson B. An endotoxin-induced serum factor that causes necrosis of tumors. Proc. Natl. Acad. Sci. U S A. 1975;72 (9):3666-3670.

40. Chousterman BG, Swirski FK, Weber GF. Cytokine storm and sepsis disease pathogenesis. Semin Immunopathol. 2017;39:517-528.

41. Clark IA, Vissel B. The meteorology of cytokine storms, and the clinical usefulness of this knowledge. Semin Immunopathol. 2017;39:505-516.

42. Cohen S, Bigazzi PE, Yoshida T Similarities of T cell function in cell-mediated immunity and antibody production. Cell Immunology. 1974;12:150.

43. Dinarello CA Historical insights into cytokines. Eur J. Immunol. 2007;37:34-45.

44. Dinarello CA, Renfer L, Wolff SM. Human leukocytic pyrogen: purification and development of a radioimmunoassay. Proc Natl Acad Sci U S A. 1977;74(10):4624-4627.

45. Elenkov IJ, Chrouros GP. Stress hormones, proinflammatory and antiinflammatory cytokines, and autoimmunity. Ann N. Y. Acad Sci. 2002;966:290-303.

46. Ferrara JL, Abhyankar S, Gilliland DG. Cytokine storm of graft-versus-host disease: a critical effector role for interleukin-1. Transplant Proc. 1993;25(1 Pt 2):1216-1217.

47. Fessler JH, Cooper KE, Cranston WI, Vollum RL. Observations on the production of pyrogenic substances by rabbit and human leucocytes. J. Exp Med. 1961;1(113):11271140 .

48. Fleischmann C, Scherag A, Adhikari NK, Hartog CS, Tsaganos T, Schlattmann P. International Forum of Acute Care Trialists. Assessment of global incidence and mortality of hospital-treated sepsis. Current estimates and limitations. International Forum of Acute Care T Am J Respir Crit Care Med. 2016;193(3):259-272. 
49. Gadek-Michalska A, Bugajski AJ, Bugajski JJ. Prostaglandins and interleukin-1beta in the hypothalamic-pituitary-adrenal response to systemic phenylephrine under basal and stress conditions. Physiol Pharmacol. 2008;59(3):563-575.

50. Isaacs A, Lindenmann J. Virus interference I. The interferon. Proceedings of the Royal Society of London. Series B: Biological science. 1957;147(927):258-267.

51. Jankowsky JL, Patterson PH. The role of cytokines and growth factors in seizures and their sequelae. Prog. Neurobiol. 2001;63(2):125-149.

52. Margeli A, Skenderi K, Tsironi M, Hantzi E, Matalas AL, Vrettou C, et al. Elevations of Interleukin-6 and acute-phase reactants in athletes participating in the ultradistance foot race spartathlon: Severe systemic inflammation and lipid and lipoprotein changes in protracted exercise. J. Clinical Endocrinology \& Metabolism. 2005;90(7):3914-3918.

53. Pedersen BK, Bruunsgaard H, Ostrowski K, Krabbe K, Hansen H, Krzywkowski K, et al. Cytokines in aging and exercise. Int. J. Sports Med. 2000;21(1):4-9.

54. Rich AR, Lewis MR. The nature of allergy in tuberculosis as revealed by tissue culture studies. Bull., Johns Hopkins Hosp. 1932;50:115-131.

55. Steensberg A, van Hall G, Osada T, Sacchetti M, Saltin B, Pedersen BK. Production of interleukin-6 in contracting human skeletal muscles can account for the exercise-induced increase in plasma interleukin-6. J. Physiology. 2000;529(1):237-242.

56. Waksman BH, Matoltsy M. Quantitative study of local passive transfer of tuberculin sensitivity with peritoneal exudate cells in the guinea pig. J. Immunol. 1958;81(3):235241.

57. Wu HP, Chen CK, Chung K, Tseng JC, Hua CC, Liu YC, et al. Serial cytokine levels in patients with severe sepsis. Inflamm Res. 2009;58(7):385-393.

58. Zinsser H. Tamiya T. An experimental analysis of bacterial allergy. J. Exp. Med. 1926;44 (6):753-776.

\section{REFERENCES}

1. Babiychuk VG. Soderzhanie tsitokinov $\mathrm{v}$ syvorotke krovi posle ritmicheskikh kholodovykh vozdeystviy. Problemy kriobiologii. 2007;17(4):356-364. [in Russian].

2. Vastyanov RS, Oleynik FF. Neyrotropnye effekty tsitokinov i faktorov rosta. Uspekhi fiziol. nauk. 2007;38(1):39-54. [in Russian].

3. Hasyuk OM, Beschasnyi SP. Interleykinovyi profil ditey v umovakh slukhovoi sensornoi deryvatsii. Ukrainskyi zhurnal medytsyny, biolohii ta sportu. 2016;1(1):126-129. [in Ukrainian].

4. Kalinichenko LS. Tsitokiny $\mathrm{v}$ regulyatsii okislitelnykh $\mathrm{i}$ antioksidantnykh protsessov $\mathrm{v}$ strukturakh golovnogo mozga u krys pri ostrom emotsionalnom stresse [avtoreferat]. Moskva: Nauchno-issledovatelskiy institut normalnoy fiziologii imeni P.K. Anokhina; 2012. 26 p. [in Russian].

5. Ketlinskiy SS, Simbirtsev AS. Tsitokiny. Moskva: Foliant; 2008. 552 p. [in Russian].

6. Kozlov VK. Tsitokinoterapiya: patogeneticheskaya napravlennost pri infektsionnykh zabolevaniyakh i klinicheskaya effektivnost: Rukovodstvo dlya vrachey. Sankt-Peterburg: Alter Ego; 2010. 148 p. [in Russian].

7. Levichkin VD, Trofimenko AI, Kade AKh, Pavlyuchenko II, Myasnikova VV, Pirogova $\mathrm{NP}$, Zanin SA. Kharakteristika tsitokinovogo profilya i oksidativnogo statusa u krys $\mathrm{s}$ eksperimentalnym ishemicheskim insultom. Sovremennye problemy nauki i obrazovaniya. 2014;6:321. [in Russian]. 
8. Lomako VV, Shilo AV, Lomako SV, Babiychuk GA. Etologicheskiy analiz sochetannogo primeneniya kholodovoy i kletochnoy terapii u krys s rezerpinovoy modelyu depressii. Probl. kriobiologii. 2005;15(3):471-472. [in Russian].

9. Meerson FZ, Pshennikova MG. Adaptatsiya k stressornym situatsiyam i fizicheskim zagruzkam. Moskva: Meditsina; 1988. 256 p. [in Russian].

10. Ovanesyan IG. Sovremennye predstavleniya o roli tsitokinov v gomeostaze. Nauchnomeditsinskiy zhurnal. 2006;4:8-17. [in Russian].

11. Oradova ASh, Ustenova GO, Stabaeva GS. Metody issledovaniya tsitokinov (obzornaya statya). Medicine. 2014;10:84-87. [in Russian].

12. Pavlova AA, Pavlova IE, Bessmeltsev SS. Tsitokiny i ikh rol $v$ patogeneze mnozhestvennoy mielomy (Obzor literatury). Gematologiya. 2013;14:313-335. [in Russian].

13. Pavlova VI, Mamylina NV. Uroven provospalitelnykh i protivovospalitelnykh tsitokinov v krovi u zhivotnykh, podvergshikhsya deystviyu emotsionalno-bolevogo stressa. Tsitokiny i vospalenie. 2012;11(1):46-48. [in Russian].

14. Paltsev MA. Tsitokiny i ikh rol v mezhkletochnykh vzaimodeystviyakh. Arkhiv patologii. 1996;6:3-7. [in Russian].

15. Radzhabkadiev RM, Riger NA, Nikityuk DB, Galstyan AG, Petrov AN, Evsyukova AO i dr. Sopostavlenie urovnya immunoregulyatornykh tsitokinov i nekotorykh antropometricheskikh pokazateley vysokokvalifytsirovannykh sportsmenov. Meditsinskaya immunologiya. 2018;20(1):53-60. [in Russian].

16. Saraykin DA. Funktsionalnoe sostoyanie organizma yunykh sportsmenov na raznykh etapakh trenirovochnogo protsessa [avtoreferat]. Chelyabinsk: Chelyabinskiy gosudarstvennyi pedagogicheskiy universitet; 2012. 24 p. [in Russian].

17. Sarkisov S., redaktor. Strukturnye osnovy adaptatsii i kompensatsii narushennykh funktsiy. Moskva: Meditsina; 1987. 446 p. [in Russian].

18. Sele G. Ocherki ob adaptatsionnom sindrome / G. Sele. Moskva: Medgiz; 1960. 254 p. [in Russian].

19. Serebrennikova SN, Seminskiy IZh. Vliyanie tsitokinov na kletki ochaga vospaleniya. Problemy i perspektivy sovremennoy nauki. 2009;2(1):5-9. [in Russian].

20. Sydorchuk AS, Bohachyk NA, Venhlovska YaV. Rol systemy tsytokiniv u patohenezi hrypu. Klinichna ta eksperymentalna patolohiya. 2008;7(2):130-133. [in Russian].

21. Symbyrtsev AS. Tsytokyny - novaya systema rehulyatsyi zashchytnykh reaktsyi orhanyzma. Tsytokyny y vospalenye. 2002;1:9-16. [in Russian].

22. Symbyrtsev AS. Tsytokyny: klassyfykatsyya y byolohycheskye funktsyi. Tsytokyny y vospalenye. 2004;3(2):16-22. [in Russian].

23. Solodkov AP, Yatskovskaya NM, Kraynova NA, Nechaev YN, Knyazev EN, Maksymenko DH. Provospalytelnye tsytokyny y endotelyizavysymaya dylatatsyya pry ostrom stresse. Fundamentalnye y prykladnye problemy stressa. Materyaly III Mezhdunar. nauch.-prakt. konf.; Vytebsk. Vytebsk: VHU ymeny P.M. Masherova; 2013, p. 83-87. [in Russian].

24. Statsenko EA. Profylaktyka y korrektsyya narushenyi funktsyonalnoho sostoyanyya u vysokokvalyfytsyrovannykh sportsmenov $\mathrm{v}$ uslovyyakh trenyrovochnoho protsessa [avtoreferat]. Moskva: Federalnyi nauchnyi tsentr fyzycheskoy kultury y sporta; 2014. 47 p. [in Russian].

25. Stashkevych DS, Fylyppova YuYu, Burmystrova AL. Aktualnye voprosy ymmunolohyi: systema tsytokynov, byolohycheskoe znachenye, henetycheskyi polymorfyzm, metody opredelenyya : ucheb. Posobye. Chelyabynsk: Tsytsero; 2016. 82 p. [in Russian]. 
26. Trofymenko AY, Kade AKh, Levychkyn VD, Nekhay FA, Zanyn SA. Dynamyka tsytokynovoho statusa u krys pry modelyrovanyi yshemycheskoho ynsulta. Sovremennye problemy nauky y obrazovanyya. 2014;2:326. [in Russian].

27. Fursenko DV, Khotskyn NV, Kulykov VA,Kulykov AV. Povedencheskoe fenotypyrovanye myshey s nokautom po faktoru nekroza opukholy. Vavylovskyi zhurnal henetyky y selektsyi. 2015;19(4):394-398. [in Russian].

28. Futornyi SM, Imas YeV, Osadcha OI, Shmatova EA, Hlukhovskyi PV. Osoblyvosti imunolohichnoi adaptatsii pid vplyvom znachnykh fizychnykh navantazhen. Naukovyi chasopys NPU imeni M. P. Drahomanova. 2018;10(104):93-98. [in Ukrainian].

29. Khaitov PM, Ignateva GA, Sidorovich IG. Immunologiya : Uchebnik. Moskva: Meditsina; 2000. 432 p. [in Russian].

30. Khaitov RM. Immunologiya: uchebnik dlya vuzov : 2-e izd., pererab. i dop. Moskva: GEOTAR-Media; 2013. 521 p. [in Russian].

31. Chereshnev VA, Gusev EYu. Immunologiya vospaleniya, rol tsitokinov. 2001;3(3):361368. [in Russian].

32. Shipilov MV. Molekulyarnye mekhanizmy "tsitokinovogo shtorma" pri ostrykh infektsionnykh zabolevaniyakh. Lechebnoe delo. 2013;1:81-85. [in Russian].

33. Shchokina KH, Shtryhol SYu, Drohovoz SM. Dosyahnennya ta perspektyvy tsytokinovoi ta antytsytokinovoi terapii. Naukovyi zhurnal MOZ Ukrainy. 2013;1(2):121-129. [in Ukrainian].

34. Yarilin AA. Osnovy immunologii : Uchebnik. Moskva: Meditsina; 1999.608 p. [in Russian].

35. Anisman H, Merali Z. Cytokines, stress and depressive illness. Brain. Behav. Immun. 2002;16(5):513-524.

36. Bloom BR, Bennett B. Mechanism of a reaction in vitro associated withdelayed-type hypersensitivity. Science. 1966;153:80.

37. Cabral-Santos C, Gerosa-Neto J, Inoue DS, Panissa VL, Gobbo LA, Zagatto AM, et al. Similar anti-inflammatory acute responses from moderate-intensity continuous and highintensity intermittent exercise. J. Sports Science and Medicine. 2015;14:849-856.

38. Cannon JG, Evans WJ, Hughes VA Meredith CN, Dinarello CA. Physiological mechanisms contributing to increased interleukin-1 secretion. Journal of Applied Physiology. 1986;61(5):1869-1874.

39. Carswell EA, Old LJ, Kassel RL, Green S, Fiore N, Williamson B. An endotoxin-induced serum factor that causes necrosis of tumors. Proc. Natl. Acad. Sci. U S A. 1975;72 (9):3666-3670.

40. Chousterman BG, Swirski FK, Weber GF. Cytokine storm and sepsis disease pathogenesis. Semin Immunopathol. 2017;39:517-528.

41. Clark IA, Vissel B. The meteorology of cytokine storms, and the clinical usefulness of this knowledge. Semin Immunopathol. 2017;39:505-516.

42. Cohen S, Bigazzi PE, Yoshida T Similarities of T cell function in cell-mediated immunity and antibody production. Cell Immunology. 1974;12:150.

43. Dinarello CA Historical insights into cytokines. Eur J. Immunol. 2007;37:34-45.

44. Dinarello CA, Renfer L, Wolff SM. Human leukocytic pyrogen: purification and development of a radioimmunoassay. Proc Natl Acad Sci U S A. 1977;74(10):4624-4627.

45. Elenkov IJ, Chrouros GP. Stress hormones, proinflammatory and antiinflammatory cytokines, and autoimmunity. Ann N. Y. Acad Sci. 2002;966:290-303.

46. Ferrara JL, Abhyankar S, Gilliland DG. Cytokine storm of graft-versus-host disease: a critical effector role for interleukin-1. Transplant Proc. 1993;25(1 Pt 2):1216-1217. 
47. Fessler JH, Cooper KE, Cranston WI, Vollum RL. Observations on the production of pyrogenic substances by rabbit and human leucocytes. J. Exp Med. 1961;1(113):11271140.

48. Fleischmann C, Scherag A, Adhikari NK, Hartog CS, Tsaganos T, Schlattmann P. International Forum of Acute Care Trialists. Assessment of global incidence and mortality of hospital-treated sepsis. Current estimates and limitations. International Forum of Acute Care T Am J Respir Crit Care Med. 2016;193(3):259-272.

49. Gadek-Michalska A, Bugajski AJ, Bugajski JJ. Prostaglandins and interleukin-1beta in the hypothalamic-pituitary-adrenal response to systemic phenylephrine under basal and stress conditions. Physiol Pharmacol. 2008;59(3):563-575.

50. Isaacs A, Lindenmann J. Virus interference I. The interferon. Proceedings of the Royal Society of London. Series B: Biological science. 1957;147(927):258-267.

51. Jankowsky JL, Patterson PH. The role of cytokines and growth factors in seizures and their sequelae. Prog. Neurobiol. 2001;63(2):125-149.

52. Margeli A, Skenderi K, Tsironi M, Hantzi E, Matalas AL, Vrettou C, et al. Elevations of Interleukin-6 and acute-phase reactants in athletes participating in the ultradistance foot race spartathlon: Severe systemic inflammation and lipid and lipoprotein changes in protracted exercise. J. Clinical Endocrinology \& Metabolism. 2005;90(7):3914-3918.

53. Pedersen BK, Bruunsgaard H, Ostrowski K, Krabbe K, Hansen H, Krzywkowski K, et al. Cytokines in aging and exercise. Int. J. Sports Med. 2000;21(1):4-9.

54. Rich AR, Lewis MR. The nature of allergy in tuberculosis as revealed by tissue culture studies. Bull., Johns Hopkins Hosp. 1932;50:115-131.

55. Steensberg A, van Hall G, Osada T, Sacchetti M, Saltin B, Pedersen BK. Production of interleukin-6 in contracting human skeletal muscles can account for the exercise-induced increase in plasma interleukin-6. J. Physiology. 2000;529(1):237-242.

56. Waksman BH, Matoltsy M. Quantitative study of local passive transfer of tuberculin sensitivity with peritoneal exudate cells in the guinea pig. J. Immunol. 1958;81(3):235241.

57. Wu HP, Chen CK, Chung K, Tseng JC, Hua CC, Liu YC, et al. Serial cytokine levels in patients with severe sepsis. Inflamm Res. 2009;58(7):385-393.

58. Zinsser H. Tamiya T. An experimental analysis of bacterial allergy. J. Exp. Med. 1926;44 (6):753-776.

Стаття надійила до редакиії 06.12.2019.

The article was received 06 December 2019. 